\title{
THE ESTIMATION OF SEISMIC PERFORMANCES OF REINFORCED CONCRETE GIRDER BRIDGES USING NONLINEAR DYNAMIC ANALYSIS
}

\author{
Andrija Rašeta, Đorđe Lađinović, Aleksandra Radujković
}

Original scientific paper

The paper applies nonlinear dynamic analysis to estimate seismic performances of reinforced concrete girder bridges. In all analysed variations, the structure of the beam implies the continual girder with four fields $(35 \mathrm{~m}+50 \mathrm{~m}+50 \mathrm{~m}+35 \mathrm{~m})$ hinged to the pier tops and the abutments. The piers are completely fixed to the ground with the lengths of $7 \mathrm{~m}, 14 \mathrm{~m}$ and $21 \mathrm{~m}$; hence, 18 diverse combinations of pier lengths have been analysed. Geometric nonlinearity is included via the $P-\Delta$ effect, while the material nonlinearity is included into the analyses using the fibre models of plastic hinges. The estimation of seismic performances has been calculated on the basis of the demanded local ductility and the local ductile capacity of the critical crosssections in the piers of all bridge analysed variations. Artificially (synthetically) generated and recorded earthquake accelerograms have been utilized for nonlinear dynamic analyses.

Keywords: nonlinear dynamic analysis; RC girder bridges; seismic performances

Procjena seizmičkih performansi grednih armiranobetonskih mostova nelinearnom dinamičkom analizom

Izvorni znanstveni članak

U ovom radu je za procenu seizmičkih performansi grednih armiranobetonskih mostova primijenjena nelinearna dinamička analiza. U svim analiziranim varijantama konstrukcija grede mosta jeste kontinuirni nosač sa četiri polja $(35 \mathrm{~m}+50 \mathrm{~m}+50 \mathrm{~m}+35 \mathrm{~m})$ i zglobno je oslonjena na vrhove stubova $\mathrm{i}$ krajnje oporce. Stubovi su potpuno uklješteni u tlo sa dužinama $7 \mathrm{~m}, 14 \mathrm{~m}$ i $21 \mathrm{~m}$, tj. analizirano je 18 različitih kombinacija dužina stubova. Geometrijska nelinearnost se obuhvaća preko $P-\Delta$ efekta, a materijalna nelinearnost se uključuje u analize kroz vlaknaste modele plastičnih zglobova. Procjena seizmičkih performansi je izračunata na osnovu zahtijevane lokalne duktilnosti i kapaciteta lokalne duktilnosti koje posjeduju kritični poprečni presjeci u stubovima analiziranih varijanti mostova. Za nelinearne dinamičke analize upotrebljeni su umjetno (sintetički) generirani i realni zapisi zemljotresa.

Ključne riječi: gredni AB mostovi; nelinearna dinamička analiza; seizmičke performase

\section{Introduction}

The primary goal in designing structures in seismically active areas is to provide adequate structure safety and performance during and after an earthquake. When bridges are considered, the seismic design should provide an adequate functionality after an earthquake. The degree of this functionality depends primarily on the earthquake strength, structure philosophy and quality in all design phases and performance criteria. Bridges are classified in the appropriate categories in accordance with their importance. Classification in each category depends on the consequences of their collapse on human lives and of their importance for maintaining communication immediately after the earthquake. Also, the economic collapse consequences should not be forgotten. After this consideration, the factor of significance will be determined in relation to the return period of the seismic event, which is further used in determining the components of design ground acceleration on the type $\mathrm{A}$ ground (EN 1998-2 [1]).

Today, there are procedures for controlling the existing and for designing new structures in seismically active areas that are based on the performance of a structure $[12,2]$. The main elements in the seismic estimation on the structure performance include seismic hazard and the estimation of the seismic structural demand. The calculated seismic demand is compared with the acceptable damage level. Since the damage appearance in structural elements has nonlinear behaviour as a consequence, it is essential to use nonlinear analysis methods for determining seismic demands $[10,3]$. Seismic demand estimation is related to the estimation on a global and a local level. Global demands are most often related to the maximum displacement of the control node, i.e. to the ratio between the base shear and the control node displacement. Local demands are most commonly related to the estimation of relative displacement between individual structural nodes, plastic rotation of critical cross sections and chord rotation of individual structural elements.

The goal of the research in the paper is to perceive the behaviour of reinforced concrete girder bridges under strong seismic action designed on the basis of a linearelastic model (EN 1992-1-1 [4], EN 1998-1 [5] and EN 1998-2 [1]). The analysed parameter for estimating the seismic performances is the ratio between the demanded local ductility and the local ductile capacity of the critical cross-sections in the piers.

The main behaviour demands in designing reinforced concrete girder bridges in seismically active areas [1] are to prevent the structure from failure and to limit the damage level for the designed seismic action. Likewise, it is necessary for the response of the bridge beam to be in the linear-elastic area with the goal of providing minimum conditions for traffic. The most common elements where the controlled damage is allowed are bridge piers.

In the zones of high seismicity, due to rationality, bridges are designed as structures with ductile behaviour, while in other zones they have restricted ductility. For the ultimate limits states, it has to be proven that the structural system has the resistance and capacity for energy dissipation stated in the appropriate segments of EN 1998-1 and EN 1998-2. The resistance and capacity of energy dissipation in a structure are related to the level of the expected nonlinear response. In the operational sense, the balance between the resistance and the capacity of energy dissipation is characterised by the behaviour factor 
value. In the boundary case, in designing structures classified as low-dissipative, any hysteresis energy dissipation cannot be considered at all, while, generally, the behaviour factor cannot be higher than the value 1.5. For dissipative structures of reinforced concrete bridges the maximum permissible behaviour factor value is 3,5 , considering also the hysteresis energy dissipation that primarily happens in specially designed zones known as the dissipative zones or critical areas. For bridges, the demands for ultimate limit states related to the designed earthquake action are stricter than the relevant demands for buildings, since they contain demands for traffic functions in extraordinary situations.

EN 1998-2 prescribes conditions for structural modelling of critical areas from the aspects of volume and arrangement of longitudinal and shears reinforcement that is used to achieve local ductility capacity that directly influences the global system behaviour, all of them depending on the adopted behaviour.

The paper presents the analysis of reinforced concrete girder bridges with the continual girder (four fields $35 m+50 m+50 m+35 m$ ) hinged to the pier tops and the abutments. The piers are fixed to the ground with the different lengths $(7 \mathrm{~m}, 14 \mathrm{~m}$ and $21 \mathrm{~m})$. It has been analysed 18 different combinations of pier lengths (Tab. 1). Geometric nonlinearity is included via the $P-\triangle$ effect. The material nonlinearity is included into the analyses using the fibre models of plastic hinges. The estimation of seismic performances has been calculated on the basis of the demanded local ductility and the local ductile capacity of the critical cross-sections in the piers.

\section{Modelling methods and analyses}

In this paper, the finite element method is used for linear and nonlinear static and dynamic analyses of reinforced concrete girder bridges. Nonlinear dynamic analysis includes material nonlinearity by applying the fibre model of a plastic hinge [6] and geometric nonlinearity via the $P-\Delta$ effect. For numerical calculations, the incremental iterative procedure with Newton-Raphson procedure [7] has been applied.

Since the damage occurrence in all analysed variations of reinforced concrete girder bridges in this research is permitted only in piers, a special attention should be attributed to their structural modelling. All analysed bridge structures have their piers completely fixed to the ground and hinged to the beam. The consequence of this design is the fact that nonlinear deformations can occur in the fixed areas of piers.

The effective moment of inertia $J_{\text {eff }}$ of cross sections can be determined with the expression (EN 1998-2):

Method 1: $\quad J_{\text {eff }}=0,08 J_{\text {un }}+J_{\text {cr }} \quad\left(J_{\text {cr }}=M_{y} /\left(E_{\mathrm{c}} \Phi_{y}\right)\right.$

Method 2: $\quad E_{\mathrm{c}} J_{\mathrm{eff}}=v M_{\mathrm{Rd}} / \Phi_{y}$

where: $J_{\text {un }}$-moment of inertia of the uncracked cross section, $J_{\mathrm{cr}}-$ moment of inertia of the cracked section, $M_{y}$ - moment of bending on the yield limit, $\Phi_{y}-$ the yield curvature, $E_{\mathrm{c}}$ - module of elasticity for concrete, $v-$ correction coefficient, whose proposed value is 1,2 , and $M_{\mathrm{Rd}}-$ design value of flexural strength. The bending moment and the curvature on the yield limit can be determined by the bilinearisation of the nonlinear relation of the moment-curvature (Fig. 1 [1]).

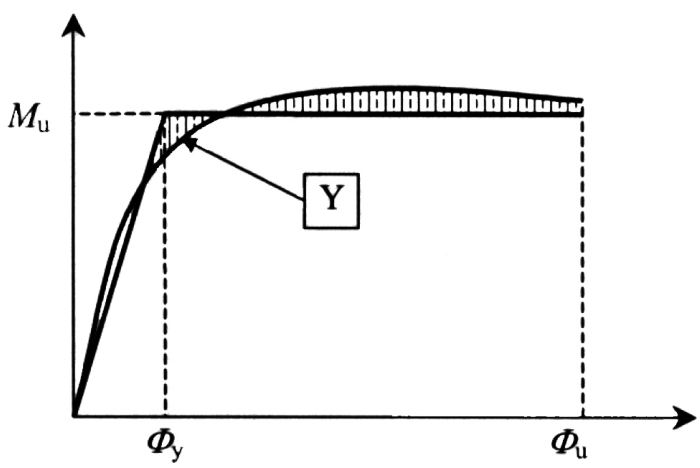

Figure $1 M-\Phi-$ EN $1998-2$ ( $Y$ - yield of the first bar) [1]

Nonlinear relations between stress and strain are specially determined for the unconfined and confined segment of cross section and longitudinal reinforcement $([4,[1])$. Relation between inner forces and relative displacements is introduced into the dynamic analysis via the hysteresis rule. In all analysed bridge variations in this research, the uniaxial bilinear model of the relation stressstrain with linear hardening is applied for the reinforcement, and the Mander model $([1,11])$ and the Takeda model of hysteresis behaviour are applied for the concrete part of the section. Fibre cross section is presented in Fig. 2.

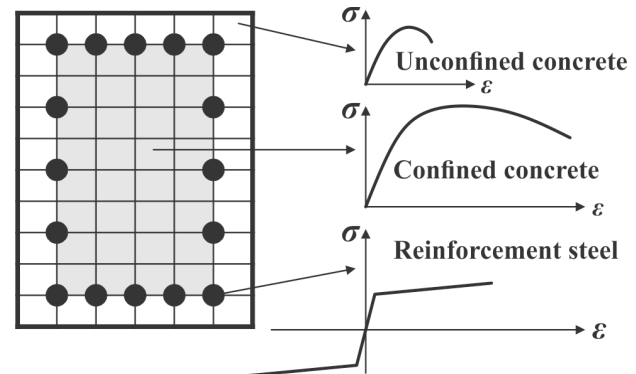

Figure 2 Fibre model for RC cross section

Modes for modelling the plastification zone in bridge piers [8] are presented in Fig. 3. In the first case (Fig. 3a), the plastic hinge is applied into the middle of the zone length where cross section plastification can occur (the length of the critical zone is equal to the length of the plastic hinge $L_{\mathrm{p}}$ ), while in the second case (Fig. 3b), the zone predicted for allowing plastification is modelled with two finite elements, each of them adjoined with the plastic hinge whose length equals a half of the length of the critical zone.

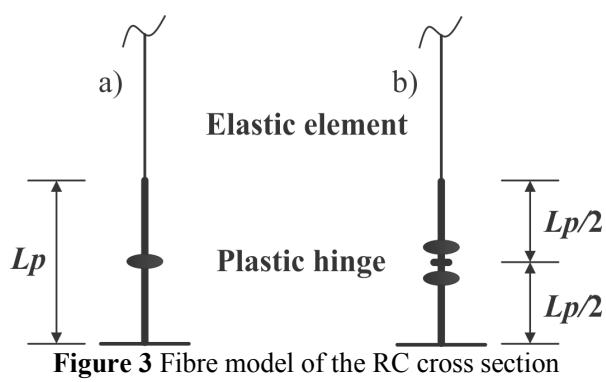


The length of the plastic hinge $L_{\mathrm{p}}$ can be determined depending on the distance between the plastic hinge and the zero value of the bending moment in the pier $L(\mathrm{~m})$, characteristic tensile reinforcement strength $f_{y \mathrm{k}}(\mathrm{MPa})$ and longitudinal reinforcement cross section $d_{\mathrm{bl}}(\mathrm{m})[1]$ :

$$
L_{\mathrm{p}}=0,1 L+0,015 f_{y \mathrm{k}} d_{\mathrm{bl}}
$$

Seismic action for the nonlinear dynamic analysis can be a recorded and/or an artificial earthquake. In [1], there are prescribed rules for the selected earthquakes, which their records (accelerograms) have to satisfy. Generally, earthquakes should be selected from recorded events with magnitudes, source distances, and mechanisms consistent with those that define the design seismic action. The minimum number of earthquakes that can be used in analyses is three. If seven or more earthquakes are used, the average results of them all can be utilized, while if less than seven earthquakes are used, the extreme result values are observed.

\section{Numerical Analysis}

The paper analyses reinforced concrete girder bridges with diverse combinations of pier lengths. All analyses and dimensioning are performed according to [4], [5] and [1]. Tab. 1 states all combinations of pier lengths (27 combinations), and only the analysed ones are emphasised (dark cells - 18 combinations), since some of the combinations are being repeated due to the system symmetry. Pier lengths are adopted with the values $7 \mathrm{~m}$, $14 \mathrm{~m}$ and $21 \mathrm{~m}$.

Table 1 Combinations of pier lengths of the analysed $\mathrm{RC}$ girder bridges

\begin{tabular}{|l|l|l|l|l|l|l|l|l|l|}
\hline \multicolumn{7}{|c|}{ Combinations of pier length of the analysed RC girder bridges } & Note \\
\hline V111 & V112 & V113 & V121 & V122 & V123 & V131 & V132 & V133 & 1 - pier length $7 \mathrm{~m}$ \\
\hline V211 & V212 & V213 & V221 & V222 & V223 & V231 & V232 & V233 & 2 - pier length $14 \mathrm{~m}$ \\
\hline V311 & V312 & V313 & V321 & V322 & V323 & V331 & V332 & V333 & 3 - pier length 21 m \\
\hline
\end{tabular}

Properties of the structures of the analysed bridges are presented in Fig. 4 and 5. The bridge beam is a continual static system on four fields (spans: $35 m+50 m+50 m+35 m)$ with the total length of $170 \mathrm{~m}$, and it is hinged to the pier tops and the abutments.
Piers are fixed to the ground. In the longitudinal direction, all three piers are engaged, while in the transverse direction all piers and abutments that prevent the displacement for the beam ends are engaged.

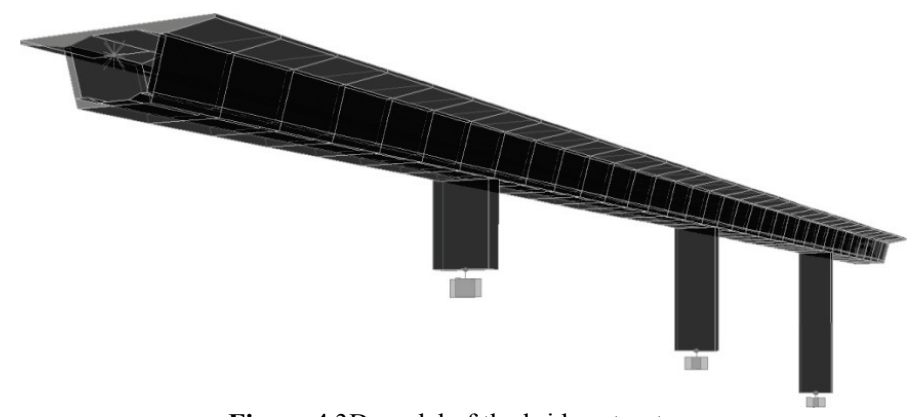

Figure 4 3D model of the bridge structure

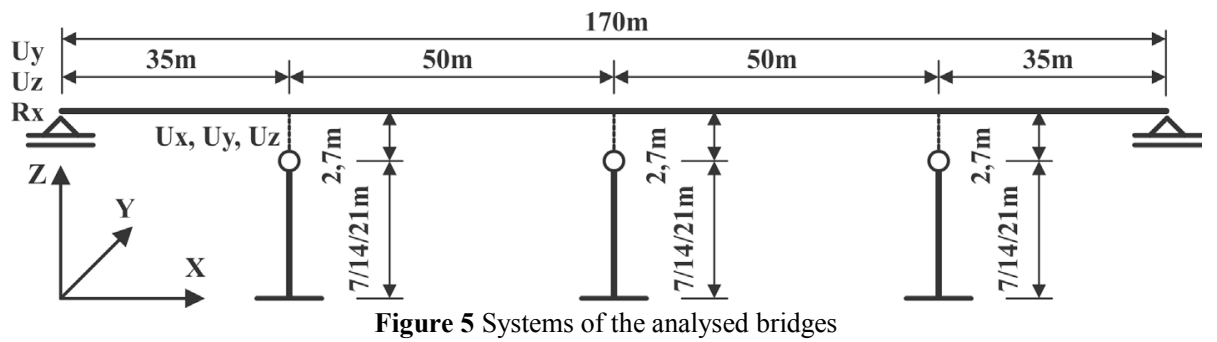

The beam in the analysed bridge variants has a box cross section (Fig. 6 left). Geometric and mechanical properties of the beam cross section are as follows: $A_{1}=10,41 \mathrm{~m}^{2}, A_{2}=4,15 \mathrm{~m}^{2}, A_{3}=6,61 \mathrm{~m}^{2}, I_{1}=39,17 \mathrm{~m}^{4}$, $I_{2}=109,02 \mathrm{~m}^{4}, I_{3}=23,74 \mathrm{~m}^{4}$ and concrete strength class C 30/37. In all analyses, torsion beam stiffness is reduced with the coefficient 0,5, while the other geometric properties are adopted to be the same as for uncracked cross section. The mass of the beam and the additional equipment is $30 \mathrm{t} / \mathrm{m}$ (total $5100 \mathrm{t}$ ).

The piers of the analysed bridges have rectangular cross section (Fig. 6 right). Depending on the analysed variant, concrete strength classes C 30/37, C 40/50 and
C 50/60 are applied. The adopted reinforcement for all bridge variations is the class $\mathrm{C}$ with the characteristic yield strength $f_{y \mathrm{k}}=500 \mathrm{MPa}$. For each combination of the pier length, the same or diverse width of the rectangular cross section is adopted for each pier individually, and all in accordance with the adequate demands in dimensioning [9]. The adopted dimensions of the pier cross section widths range from $50 \mathrm{~cm}$ to $170 \mathrm{~cm}$. The mass of the piers was determined in accordance with their cross section area for each pier individually and with the volume mass of the reinforced concrete. Axial moments of inertia and the corresponding shear surfaces of cross sections were reduced in relation to the properties of uncracked cross 
sections. Values of the reduction coefficients were determined on the basis of the results of nonlinear analysis of the ratio moment-curvature and the expression (1) for each cross section individually, ranging from 0,27 to 0,44 , depending on the adopted concrete strength class, volume and arrangement of longitudinal reinforcement, and axial stress in an element. Other geometric properties were adopted with the same values as for an uncracked cross section.
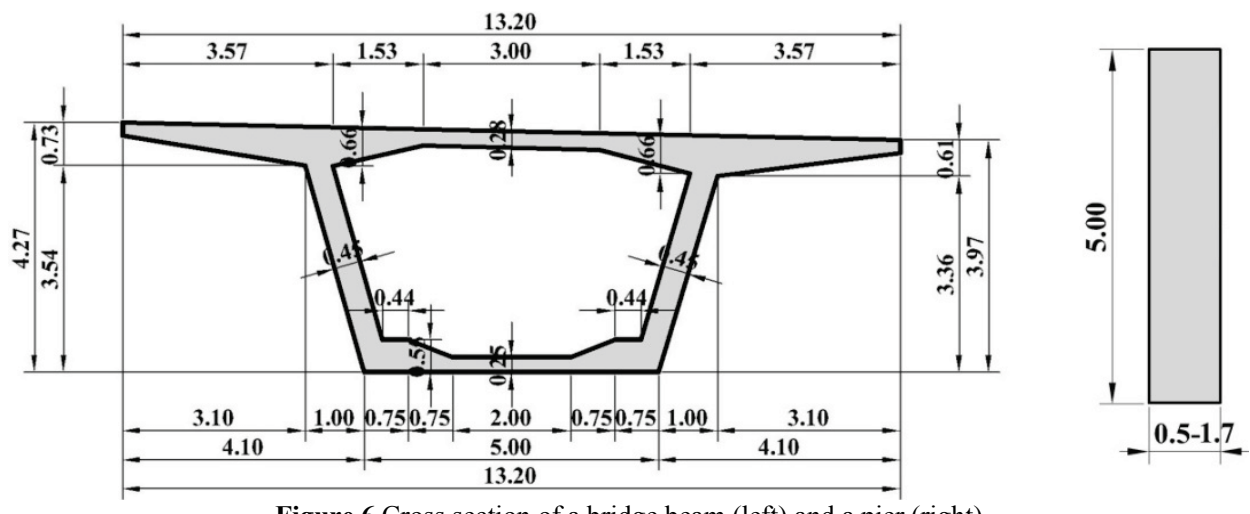

Figure 6 Cross section of a bridge beam (left) and a pier (right)

In this research, only the piers of reinforced concrete girder bridges are dimensioned since they allow the possibility for the occurrence of plastification, i.e. the damage in strong seismic action. Linear-elastic behaviour of the bridge beam is adopted for all analyses. Critical pier cross sections of all analysed bridge variations are structurally modelled as confined.

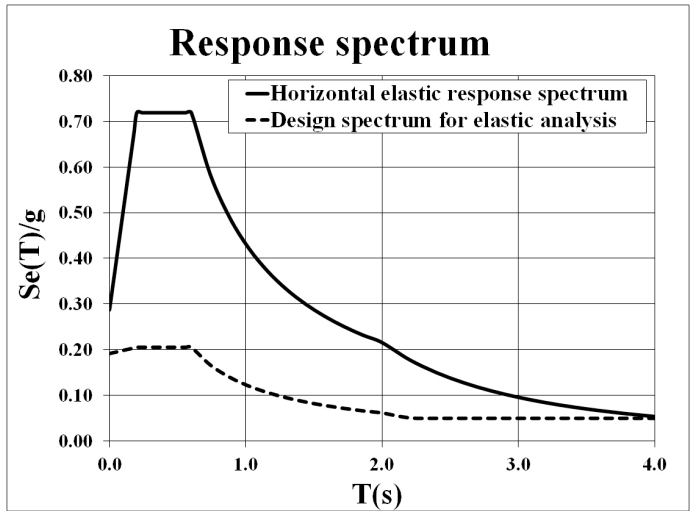

Figure 7 Elastic and designed response spectrum for the horizontal direction

The analysed bridges belong to the group with normal traffic (the mass is determined without the participation of characteristic traffic load). Considering the properties of all analysed structures, torsion effects can be neglected. All bridge variants are systems with one degree-offreedom deviation and regular behaviour in longitudinal direction. The adopted behaviour factor for the longitudinal direction is $q=3,5$. EN 1998-2 prescribes conditions for behaviour regularity control, where the behaviour factor for the observed direction is reduced in the case of irregular behaviour. Considering the properties of analysed bridges, irregular behaviour can be expected in the transverse direction. Likewise, as alternatives to linear methods, EN 1998-2 prescribes nonlinear analysing methods, where, on the basis of rigorous nonlinear dynamic methods, in the case of irregular systems, the results of the modal analysis can be "relaxed" with response spectra, which in an operative sense means the increase in the behaviour factor. In this research, the behaviour factor $q$ in the maximum permitted amount of 3,5 for all variations of the analysed bridges is adopted for the transverse direction.

The designed seismic action is considered only in horizontal direction. The properties of the elastic and the designed response spectrum (Fig. 7) for the horizontal direction are as follows: type 1 of elastic response, $a_{\mathrm{g}}=0,25 \mathrm{~g}$, soil category $-\mathrm{C}$, damping of $5 \%, q=3,5$ and $\beta=0,2$.

Values of the undamped free vibrations of the first mode for every analysed bridge variation are presented in Tab. 2.

Table 2 Individual vibration periods of the first mode $T_{1}$ (s)

\begin{tabular}{|c|c|c|c|c|c|}
\hline & $\begin{array}{c}\text { Longitud. } \\
\text { direction } \\
T_{1}(\mathrm{~s})\end{array}$ & $\begin{array}{c}\text { Transv. } \\
\text { direction } \\
T_{1}(\mathrm{~s})\end{array}$ & $\begin{array}{c}\text { Longitud. } \\
\text { direction } \\
T_{1}(\mathrm{~s})\end{array}$ & $\begin{array}{c}\text { Transv. } \\
\text { direction } \\
T_{1}(\mathrm{~s})\end{array}$ \\
\hline $\mathrm{V} 111$ & 0,91 & 0,25 & $\mathrm{~V} 212$ & 1,09 & 0,41 \\
\hline $\mathrm{V} 112$ & 0,81 & 0,38 & $\mathrm{~V} 213$ & 0,91 & 0,42 \\
\hline $\mathrm{V} 113$ & 0,81 & 0,40 & $\mathrm{~V} 222$ & 3,44 & 0,67 \\
\hline $\mathrm{V} 121$ & 0,81 & 0,41 & $\mathrm{~V} 223$ & 3,09 & 0,68 \\
\hline $\mathrm{V} 122$ & 1,09 & 0,56 & $\mathrm{~V} 232$ & 3,09 & 0,80 \\
\hline $\mathrm{V} 123$ & 1,11 & 0,63 & $\mathrm{~V} 233$ & 3,02 & 0,89 \\
\hline $\mathrm{V} 131$ & 0,79 & 0,46 & $\mathrm{~V} 313$ & 0,92 & 0,43 \\
\hline $\mathrm{V} 132$ & 1,08 & 0,65 & $\mathrm{~V} 323$ & 3,02 & 0,68 \\
\hline $\mathrm{V} 133$ & 1,10 & 0,74 & $\mathrm{~V} 333$ & 3,48 & 0,91 \\
\hline
\end{tabular}

The arrangement for the adopted longitudinal and confinement reinforcement for the bridge pier in the middle for the variation V123 $(w / d=100 / 500 \mathrm{~cm}$, C 30/37, reinforcement class $\left.\mathrm{C}-f_{y \mathrm{k}}=500 \mathrm{MPa}\right)$ is presented in Fig. 8.

Reinforcement $\varnothing 28 / 15$, Confinement $\varnothing 12 / 12.5$

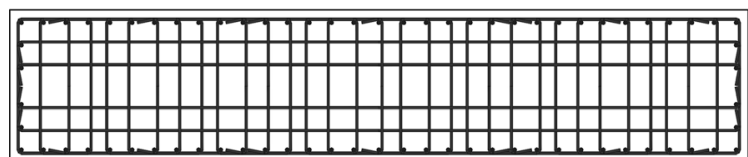

Figure 8 Adopted reinforcement for the pier in the middle - V123

The plastification zone on the place of the joint between the pier and the main structure is modelled with one finite element whose length equals the length of the 
plastic hinge $L_{\mathrm{p}}$. Plastic hinges are applied in the middle of the critical zone. The values $L_{\mathrm{p}}$ for all analysed bridge variations range between $91 \mathrm{~cm}$ and $231 \mathrm{~cm}$, and they are determined on the basis of the Eq. (2). A part of the pier outside the critical area has linear-elastic behaviour. The fibre model of the cross section for the pier in the middle for the variation V123 is presented in Fig. 9. There are individual definitions for the unconfined segment of the cross section (cover concrete), confined segment of the cross section (core concrete) and reinforcement.

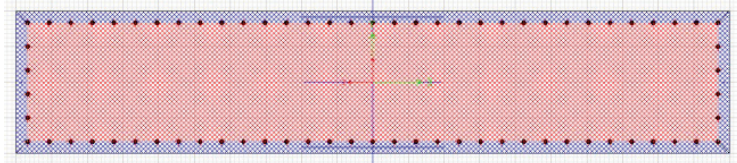

Figure 9 Fibre model of the cross section - pier in the middle - V123

Examples of the relation moment-curvature that are determined by the nonlinear analysis on the fibre model of the cross section for the pier in the middle for the variation V123 $(N=-17102 \mathrm{kN})$ are presented in Figs. 10 and 11 for the longitudinal and the transverse direction respectively.

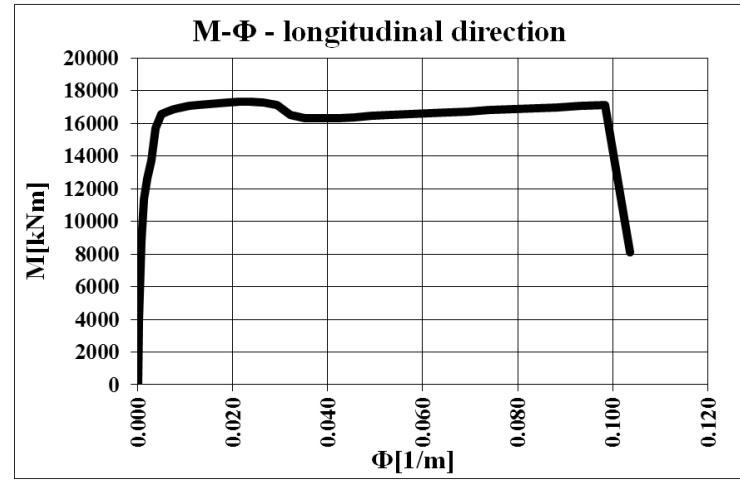

Figure $10 M-\Phi$ for the long. direction for the pier in the middle - V123

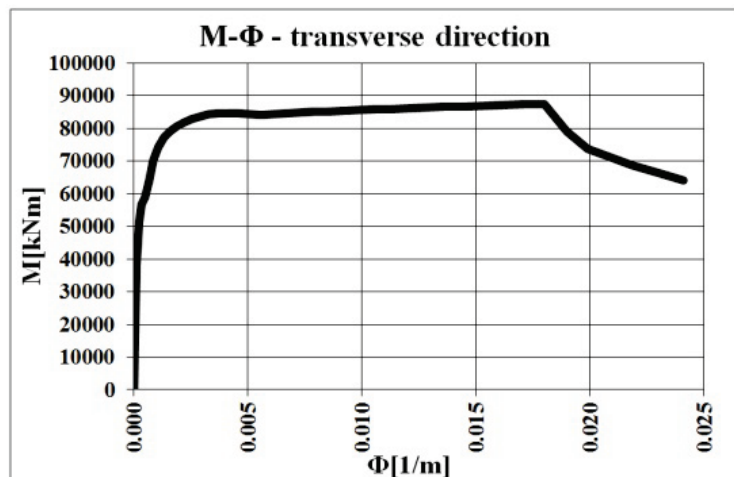

Figure $11 M-\Phi$ for the trans. direction for the pier in the middle - V123

Seismic action for nonlinear dynamic analysis is defined via three synthetic and three recorded earthquakes, and it is adopted to act only in horizontal direction. For each analysis there are two different records (accelerograms) simultaneously, one in longitudinal and the other in transverse direction of the bridge, i.e. three pairs of synthetic and three pairs of recorded accelerograms are used in the analyses. Each pair of the recorded accelerograms in one analysis responds to one real earthquake. The selected earthquakes fulfil requirements prescribed in [1]. The used recorded earthquakes are as follows: Irpinia - Italy, Loma Prieta CA, USA and Northridge 1994 - CA, USA. Figs. 12 and 13 show the average response spectra for synthetic and recorded accelerograms respectively.

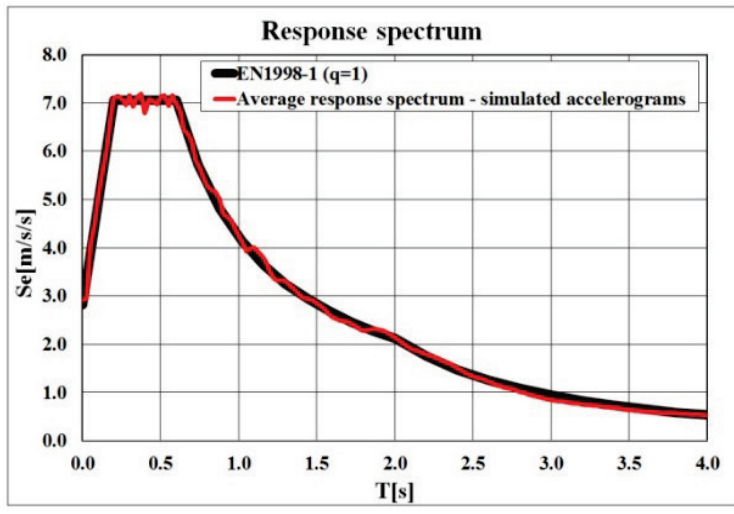

Figure 12 Average response spectrum for synthetic earthquakes

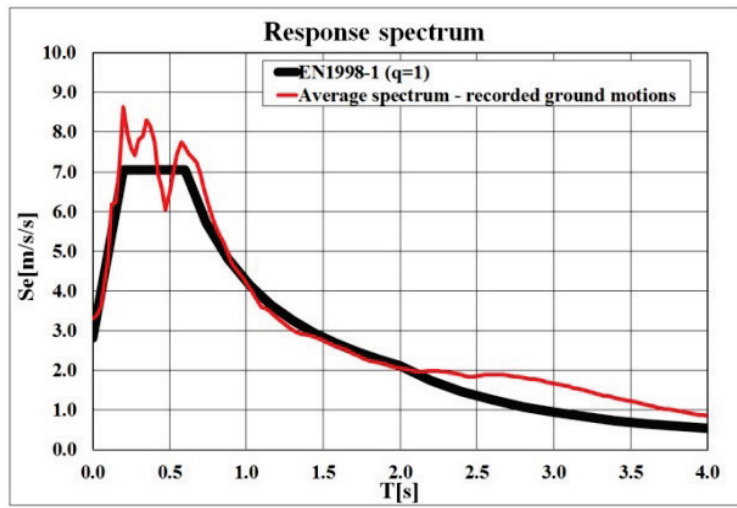

Figure 13 Average response spectrum for recorded earthquakes

With recorded accelerograms, it is not practically possible to achieve the same level of matching the average spectrum with the horizontal elastic spectrum as with artificially generated accelerograms. In the analyses with artificially generated earthquakes, smaller variations are to be expected between responses for individual records in comparison to the analysis with recorded earthquakes.

The results of the linear and nonlinear dynamic analysis for the variation V123 for the relative horizontal displacement of the middle node of the bridge beam for one synthetic and one recorded earthquake (Loma Prieta) are presented in Figs. 14 and 15. Likewise, for the same earthquakes, Figs. 16 and 17 show typical examples of relations between the bending moments and the plastic hinge rotation of the first pier $\left(L_{\text {stuba }}=7 \mathrm{~m}\right)$ in longitudinal and the pier in the middle $\left(L_{\text {stuba }}=14 \mathrm{~m}\right)$ in transverse direction.

Maximum values of the capacity of local ductility $\mu$ in critical cross sections were determined by nonlinear analysis of the cross section curvature and the plastic hinge rotation for all bridge variations (Tab. 3). Nonlinear analysis of the fibre model of the cross section and the bilinearisation of the relation moment-curvature were used to determine the curvature on the yield limit $\Phi_{y}$. The rotation of the plastic hinge on the yield limit $\theta_{y}$ was determined as the product of the curvature on the yield limit $\Phi_{y}$ and the appropriate length of the plastic hinge $L_{\mathrm{p}}$. 

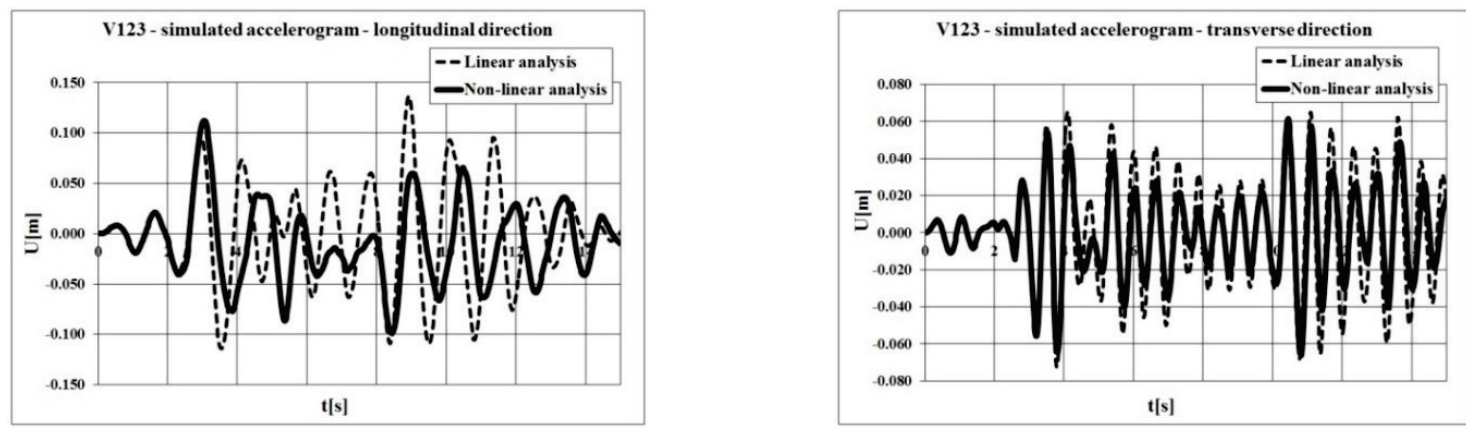

Figure 14 Relative horizontal displacement of the middle node of the beam - artificial earthquake - V123
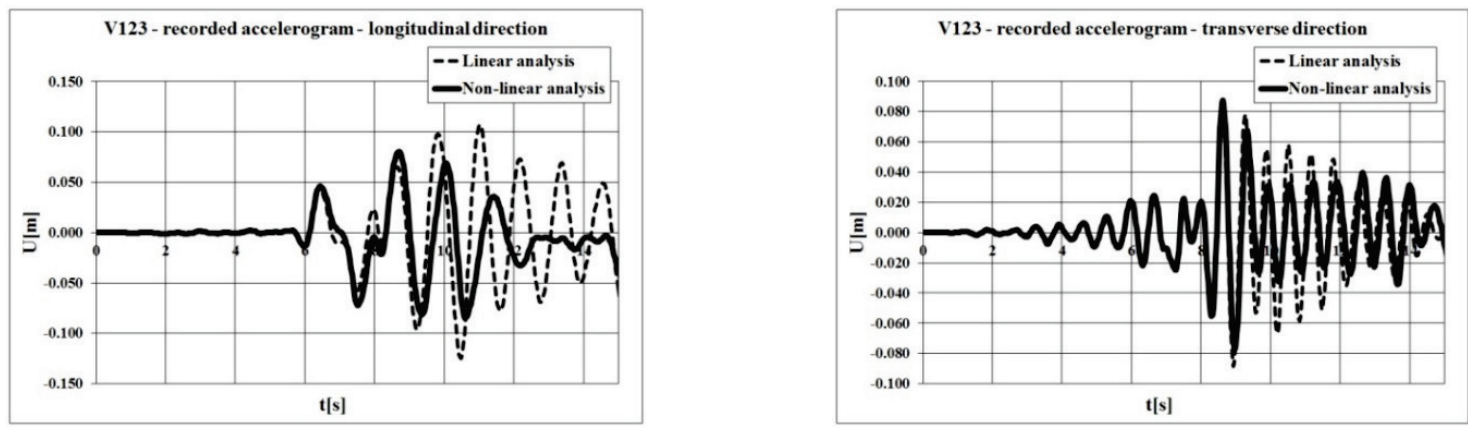

Figure 15 Relative horizontal displacement of the middle node of the beam - recorded earthquake - V123
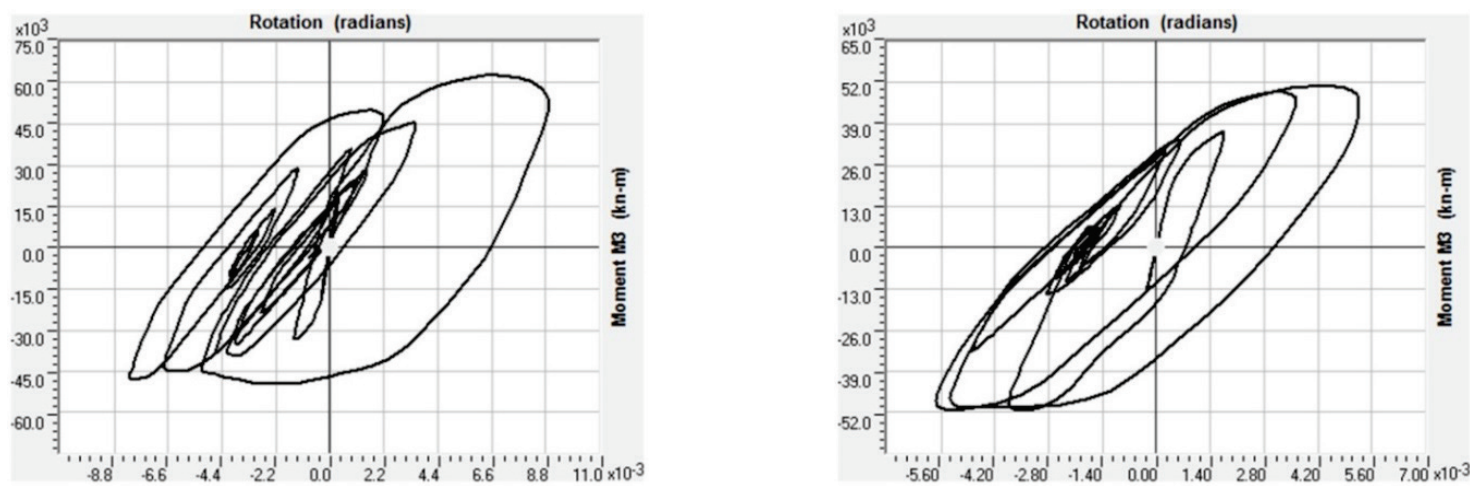

Figure 16 Relation $M-\theta$ of the first pier for the variation V123 for synthetic (left) and recorded (right) earthquake in longitudinal direction
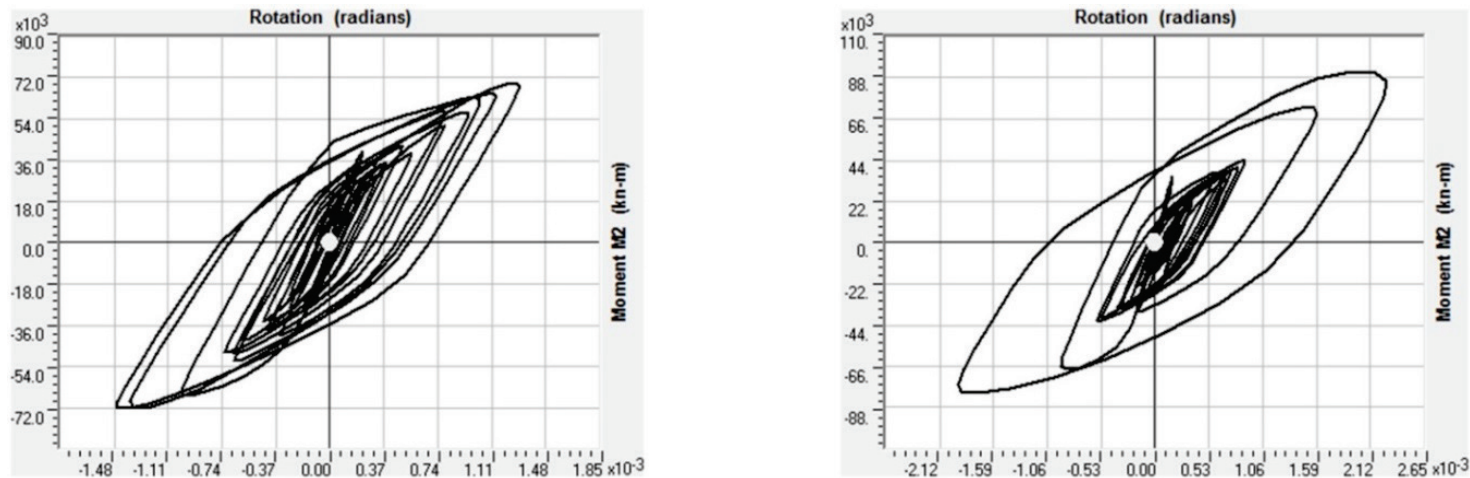

Figure 17 Relation $M-\theta$ of the pier in the middle for the variation V123 for synthetic (left) and recorded (right) earthquake in transverse direction

Table 3 The capacity of the local ductility for critical cross sections

\begin{tabular}{|c|c|c|c|}
\hline \multicolumn{2}{|c|}{ Longitudinal direction } & \multicolumn{3}{|c|}{ Transverse direction } \\
\hline$\mu_{\Phi}=\Phi_{u} / \Phi_{y}$ & $\mu_{\theta}=\theta_{u} / \theta_{y}$ & $\mu_{\Phi}=\Phi_{u} / \Phi_{y}$ & $\mu_{\theta}=\theta_{u} / \theta_{y}$ \\
\hline $12,59 \div 26,58$ & $12,60 \div 24,55$ & $14,85 \div 20,11$ & $14,86 \div 21,84$ \\
\hline
\end{tabular}

Maximum values of the demanded local ductility $\mu_{\mathrm{d}, \theta}$ determined using the nonlinear dynamic analysis for all used synthetic and recorded earthquakes are presented in Tabs. 4 and 5 respectively. Maximum demanded ductility is determined as a quotient between the maximum demanded rotation in a plastic hinge $\theta_{\text {demand, max }}$ and the rotation on the yield limit $\theta_{y}$.

Table 4 Max. demanded local ductility for synthetic earthquakes Longitudinal direction Transverse direction

$$
\begin{array}{l|l}
\multicolumn{2}{|c|}{\mu_{d, \theta}=\theta_{\text {demand, } \max } / \theta_{y}} \\
\hline \text { to } 3,85 & \text { to } 1,86
\end{array}
$$

The analysis of the order of plastic hinges and their stress-strain condition has determined that all bridge 
variations have a satisfactory capacity of inelastic deformation, since the formation of the collapse mechanism has not occurred in any case, i.e. structure failure has not occurred. An example in the order of damage occurrence, i.e. cross section plastification, is presented in Fig. 18 for the variation V123.

Table 5 Max. demanded local ductility for recorded earthquakes

\begin{tabular}{|c|c|}
\hline Longitudinal direction & Transverse direction \\
\hline \multicolumn{2}{|c|}{$\mu_{\mathrm{d}, \theta}=\theta_{\mathrm{demand} \text {, max }} / \theta_{y}$} \\
\hline to 3,57 & to 1,56 \\
\hline
\end{tabular}

Generally, with bridge variations having only one pier with the length $7 \mathrm{~m}$, the greatest values of the demanded local ductility are achieved in longitudinal and transverse directions.

The maximum value of the demanded local ductility in the longitudinal direction is 3,85 , and in the transverse direction is 1,86 . Both values are not greater than the local ductile capacity of the critical zones in the piers of the analysed bridge variants.

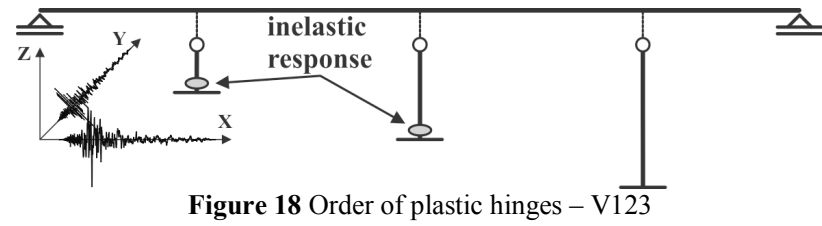

The influence of the vertical component of the ground acceleration $a_{\mathrm{v}, \text { acc }}$ onto the time history of the dynamic response was analysed for the variation V123. For seismic actions the previously, in this chapter, described accelerograms have been applied (artificially and recorded) and associated with the vertical component of ground acceleration records. Each individual combination of the three recorded accelerograms in one analysis correspond to one real earthquake. Selected earthquakes fulfill the requirements set in [1]. The results of the maximum demanded relative horizontal displacement $U_{\mathrm{d} \text {,max }}$ in the middle of the beam for one synthetic and one recorded earthquake (Loma Prieta) and the maximum demanded rotation $\theta_{\text {demand,max }}$ in plastic hinges are provided in Tabs. 6 and 7 respectively. Based on the analysis results, it can be concluded that the influence of the vertical component of the ground acceleration onto the global response $\left(U_{\mathrm{d}, \max }\right)$ is negligible. The analysis of the demanded rotations in plastic hinges with and without the vertical component of the ground acceleration implicates that the values do not differ for more than approximately $3 \%$, so it can be concluded that the influence of the vertical component of the ground acceleration on the local response is also negligible.

Table 6 The influence of the vertical component of the ground acceleration $a_{\mathrm{v}, \text { acc }}$ onto the relative horizontal deviation of the middle of the beam for the variation V123

\begin{tabular}{|c|c|c|c|c|}
\hline V123 & \multicolumn{2}{|c|}{$\begin{array}{c}\text { Simulated accel. } \\
U_{\mathrm{d}, \max }(\mathrm{cm})\end{array}$} & \multicolumn{2}{c|}{$\begin{array}{c}\text { Recorded accel. } \\
U_{\mathrm{d}, \max }(\mathrm{cm})\end{array}$} \\
\hline dir. & with $a_{\mathrm{v}, \mathrm{acc}}$ & without $a_{\mathrm{v}, \text { acc }}$ & with $a_{\mathrm{v}, \mathrm{acc}}$ & without $a_{\mathrm{v}, \mathrm{acc}}$ \\
\hline Long. & 11,2 & 11,2 & 8,5 & 8,5 \\
\hline Trans. & 6,6 & 6,6 & 8,8 & 8,8 \\
\hline
\end{tabular}

Table 7 The influence of the vertical component of the ground acceleration $a_{\mathrm{v}, \text { acc }}$ onto the maximum demanded rotation for the variation V123

\begin{tabular}{|c|c|c|c|c|c|}
\hline \multicolumn{6}{|c|}{$\theta_{\text {demand,max }}(\mathrm{rad})-\mathrm{V} 123$} \\
\hline \multirow{2}{*}{$\because$} & \multirow{2}{*}{$\cdot \frac{\bar{d}}{2}$} & \multicolumn{2}{|c|}{ Simulated accel. } & \multicolumn{2}{|c|}{ Recorded accel. } \\
\hline & & with $a_{v, a c c}$ & without $a_{v, a c c}$ & with $a_{v, a c c}$ & without $a_{v, a c c}$ \\
\hline \multirow{3}{*}{ 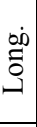 } & 1 & 0,009048 & 0,008942 & 0,005766 & 0,005739 \\
\hline & 2 & 0,002373 & 0,002332 & 0,002680 & 0,002670 \\
\hline & 3 & 0,000554 & 0,000549 & 0,000591 & 0,000585 \\
\hline \multirow{3}{*}{ 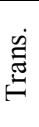 } & 1 & 0,001010 & 0,001015 & 0,001125 & 0,001119 \\
\hline & 2 & 0,001492 & 0,001455 & 0,002279 & 0,002277 \\
\hline & 3 & 0,000285 & 0,000285 & 0,000486 & 0,000486 \\
\hline
\end{tabular}

\section{Conclusions}

\subsection{General observations}

The structures of reinforced concrete girder bridges can be designed to permit the occurrence of a limited level of damage due to bending in previously defined areas. The procedure for such design is the capacity design method. The basic concept of this method is to permit damages on formerly predicted elements, i.e. plastic deformations of cross sections in bending, in order to dissipate the entered seismic energy. The elements that permit the damage occurrence should be easily accessible; hence, their repair should be simple. Furthermore, their properties should be such as to be protected from the brittle shear failure using the appropriate confinement reinforcement.

The occurrence of damage in reinforced concrete girder bridges, i.e. the plastification of cross sections due to bending, is most commonly permitted in the bridge piers. Bridge beam has to remain intact after the seismic action in order to preserve the main bridge functions (traffic for passengers and special service vehicles).

Elements that permit the plastification of cross sections due to bending are especially structurally modelled in order to provide the demanded local ductility, that is, to provide necessary capacity of deformation in bending while not permitting brittle failures.

\subsection{Conclusions and further research}

The analysis on the order of damage, i.e. on plastic hinges, implies that all analysed bridge structures have a satisfactory capacity of inelastic deformation, since no variation presented the structure failure.

Maximum values of the demanded local ductility in the longitudinal direction are achieved in the cases of the analysed bridge variations having only one pier with the length of $7 \mathrm{~m}$, while the minimum values of the demanded local ductility in the longitudinal direction are achieved in the cases of the analysed bridge variations with piers that are not shorter than $14 \mathrm{~m}$.

The maximum value of the demanded local ductility in the longitudinal direction is 3,85 , and in the transverse direction 1,86. Based on the analysis results it can be concluded that the extreme values of the demanded local ductility are not greater than the local ductile capacity of the critical cross section of the analysed bridge variants.

The value of the maximum demanded local ductility in the critical sections of all piers in the transverse 
direction for the variants V111, V112, V113 and V121 does not exceed 1,0, and it can be concluded that the response of the structure remains in the linear-elastic behaviour domain.

In the bridge variants V222, V223, V232 and V333 in the longitudinal and transverse direction the demanded maximum values of the local ductility do not exceed 1.50 , and their behaviour remains essentially in the linearelastic domain.

Based on the results of the nonlinear dynamic analysis for the variation V123, it is concluded that the vertical component of the ground acceleration does not significantly influence the local and the global response of the analysed variations of reinforced concrete girder bridges.

Further research on the estimation of seismic performances of reinforced concrete girder bridges could be related to the application of other static systems and pier cross sections. It is necessary to analyse structural systems with more pier orders having different interrelations and beam joints, as well as the number of the engaged piers in individual directions. The introduction of the interaction effects between the soil and the structure in the dynamic analysis can obtain a more realistic estimation of seismic performances. It is very difficult to predict in advance the interaction effects that are specially expressed with more rigid structures founded in the ground with not as good mechanical properties. With large span bridges, the differences in the displacement character of the foundation piers can be of interest for the introduction into the dynamic analysis. The application of the model for including nonlinear phenomena from the aspect of sliding effects, longitudinal reinforcement bar buckling and shearing deformations can be interesting for the more qualitative introduction of material nonlinearity into the analysis.

\section{Acknowledgements}

The work has been done within the scientific research project TR 36043 "Development and application of a comprehensive approach to the design of new and safety assessment of existing structures for seismic risk reduction in Serbia", which is funded by the Ministry of Science of Serbia.

\section{References}

[1] EN 1998-2:2005: Design of structures for earthquake resistance - Part 2: Bridges, European Committee for Standardization, march 2005.

[2] NHRP Synthesis 440: Performance-Based Seismic Bridge Design, A synthesis of Highway Practice, Project 20-05 (Topic 43-07), ISSN 0547-5570, ISBN 978-0-309-22380-5, Washington, D. C., 2013.

[3] Mackie, R. K.; Stojadinović, B. Seismic Demands for Performance-Based Design of Bridges, PEER 2003/16, August 2003

[4] EN 1992-1-1:2004: Design of concrete structures - Part 11: General rules and rules for buildings, European Committee for Standardization, December 2004.

[5] EN 1998-1:2004: Design of structures for earthquake resistance - Part 1: General rules, seismic actions and rules for buildings, European Committee for Standardization, December 2004.

[6] Priestley, M. J. N.; Seible, F.; Calvi, G. M. Seismic Design and Retrofit of Bridges, John Wiley \& Sons, Inc., 1996. DOI: 10.1002/9780470172858

[7] Chopra, A. K. Dynamics of Structures - Theory and Applications to Earthquake Engineering, Prentice Hall, New Jersey, 1995.

[8] Aviram, A.; Mackie, R. K.; Stojadinović, B. Guidelines for Nonlinear Analysis of Bridge Structures in California, PEER 2008/03, August 2008.

[9] Rašeta, A. Seismic Performance Analysis and Estimation of Girder Reinforced Concrete Bridges, PhD thesis, University of Novi Sad, Faculty of Technical Sciences, 2014.

[10] Fajfar, P. A Nonlinear Analysis Method for Performance Based Seismic Design. // Earthquake Spectra. (2000), pp. 573-592. DOI: 10.1193/1.1586128

[11] Mander, J. B.; Priestley, M. J. N.; Park, R. Theoretical Stress-Strain Model for Confined Concrete. // Journal of Structural Engineering. 114, 8(1988), pp. 1804-1826. DOI: 10.1061/(ASCE)0733-9445(1988)114:8(1804)

[12] Fajfar, P.; Krawinkler, H. (editors) Performance-Based Seismic Design Concepts and Implementation, Proceedings of an International Workshop, Pacific Earthquake Engineering Research Center, University of California Berkeley, PEER Report 2004/05, Bled, Slovenia, 2004.

\section{Authors' addresses}

Andrija Rašeta, PhD, Civ. Eng., Assistant Professor University of Novi Sad, Faculty of Technical Sciences, Trg Dositeja Obradovića 6, 21000 Novi Sad, Republic of Serbia E-mail: araseta@uns.ac.rs

Đorde Lađinović, PhD, Civ. Eng., Professor University of Novi Sad, Faculty of Technical Sciences, Trg Dositeja Obradovića 6, 21000 Novi Sad, Republic of Serbia E-mail: ladjin@uns.ac.rs

Aleksandra Radujković, MSc, Civ. Eng., Teaching Assistant University of Novi Sad, Faculty of Technical Sciences Trg Dositeja Obradovića 6, 21000 Novi Sad, Republic of Serbia E-mail: leksa@uns.ac.rs 